\title{
European Natural Gas Markets: Taking Stock and Looking Forward
}

\section{Chi Kong Chyong ${ }^{1}$}

Published online: 1 March 2019

(c) The Author(s) 2019

\begin{abstract}
Recent natural gas price dynamics in Europe show convergence to the extent that locational price differentials approached transport tariffs, and hence, arbitrage was largely saturated: a sign of a well-functioning pan-European gas wholesale market. This contribution seeks to understand how we got to where we are in terms of the evolution of the gas industry structure in Europe and its institutional setup. It does so using a transaction-cost economics framework. The paper concludes that the move-which is still ongoing - towards a single market in gas has allowed European gas consumers to benefit from transparently set market-based wholesale prices and increased market competition among suppliers. However, as the gas market in Europe matures and with the increased penetration of renewable energy generation in the electricity sector as well as the overall decarbonisation of the energy sector in Europe, the gas market and its current regulatory regime face a number of challenges. Addressing these challenges may require an update of the current market design and possibly drastic reforms of tariff-setting for the gas transport market.
\end{abstract}

Keywords Natural gas · Gas single market · Security of supply · Gas regulatory policy

\section{JEL Classification L94}

\section{Introduction}

European natural gas market liberalization and the process of creating a single market for natural gas started with the first reforms in England and Wales around 1990. Those reforms used unbundling and the privatization of supply and distribution of gas and electricity to enhance market competition. Since then, a number of countries

Chi Kong Chyong

k.chyong@jbs.cam.ac.uk

1 EPRG, Cambridge Judge Business School, University of Cambridge, Trumpington Str., Cambridge CB2 1AG, UK 
in Europe have followed these reforms with the aim of creating a single market for gas and electricity for all of the EU member states. By 2016, gas prices in Europe converged to the extent that locational price differentials approached the marginal cost of transporting gas, and hence arbitrage was saturated: a sign of a well-functioning pan-European wholesale gas commodity market.

This article takes stock of the evolution of the European gas industry since the 1990s and the effects of market liberalization; and it provides a sober look forward: 'quo vadis European gas market?'

The rest of this paper proceeds with the analysis of the evolution of the gas markets in Europe with the use of transaction-cost economics; it then briefly outlines the key literature with regard to gas market organisation-long-term contracts versus spot trading - and an ex post analysis of effects of gas market liberalization on price convergence. I conclude the paper with a forward look at where the European gas markets are moving and the general lessons to be learned.

\section{The Evolution of the European Gas Industry from a Transaction-Cost Economics Perspective}

The transaction-cost framework is a helpful tool for understanding the evolution and organisational complexity of the natural gas trade in Europe. The economics literature points to two major organisational forms that support exchanges between economic agents: (1) markets; and (2) vertical integration. Between those two extremes is a continuum of organisational forms that range from joint ventures to long-term contracts (LTC) (quasi-vertical integration).

The choice of organisational form depends on the characteristics of the transaction in question. Choosing an organisational form to facilitate trade has long been at the heart of economics thinking, particularly within the transaction-cost economics literature: e.g., Coase (1937; 1972); Williamson (1971, 1975, 1979, 1983, 1985); Klein et al. (1978); Klein (1980); Goldberg (1976); Goldberg and Erickson (1987); and others that follow a similar approach.

Joskow (1985) summarises the basic theory that underlies the transaction cost approach by explaining the choice of governance structure: markets, or long-term vertical relationships. In addition to the traditional cost elements that are usually incurred during any production process — such as land, labour, capital, and materials-there are also the transaction costs that are associated with the exchange of economic goods between agents: for example, costs that are related to drafting, enforcing, and potentially breaching contracts. These transaction costs are real economic costs that should be considered alongside traditional cost items in the costminimising decision-making problem.

In general, a set of characteristics may influence the nature and magnitude of transaction costs: (1) the uncertainty and complexity of transactions; (2) the need for and degree of relationship-specific sunk investments to support transactions; (3) the trade-off between the cost and benefit of internalisation versus reliance on market transactions; and (4) the regularity of transactions. 
Crucially, the need for and magnitude of relationship-specific investments to facilitate trade are the most important characteristics, which-combined with the other factors that were just mentioned-could give rise to very high transaction costs that could be associated with potential exchanges. High uncertainty means that contracts may be incomplete in the sense that they are unable to specify every possible state of nature that could affect the performance of the parties under the contract. As such, the incompleteness of contracts would not create significant problems were it not for the involvement of a high degree of relationship-specific assets that must be developed ex ante to facilitate the exchange. Furthermore, the frequency of transactions should only matter when high (sunk) investment costs were involved in establishing bilateral trade because subsequent transactions represent opportunities for haggling; and the higher is the frequency of those transactions, the higher is the risk of opportunistic behaviour among the parties that are involved in the trade.

Williamson (1983) identifies four types of asset-specificity that may partition an industry into a smaller number of bilateral oligopolies:

1. Site specificity - the vertical relationship is arranged such that related facilities are located close to one another; for example, to minimise transport and inventory costs;

2. Physical asset specificity-occurs when investments in equipment can be utilised only by one or both parties to the transaction and there is little value in utilising these assets in alternative ways;

3. Human capital specificity-occurs when employees develop specific skills required for a particular transaction; and

4. Dedicated assets - arises when investments are made only to serve a specific transaction and would not have been developed otherwise; thus, should the contract that underpins the exchanges be terminated prematurely, the dedicated asset would be underutilised.

A high transaction-cost structure was present at the beginning of the development of the natural gas industry in Europe and persisted until European authorities launched the liberalization of the electricity and gas markets. As the transaction-cost theory predicts, the European gas industry was developed based on a system of complex LTCs between buyers and sellers. LTCs drove the development of the gas trade in Europe (see Table 1), and the first such contracts were signed between European companies to develop the gas reserves of the giant Groningen gas field in the Netherlands (Energy Charter Secretariat 2007).

Table 1 highlights the importance of LTCs in the development of the gas industry in Europe: The majority of the contracts were signed in the period 1991-2007, with total contract volume signed in that period exceeding $66 \%$ of average gas consumption in that same period. Note that the majority of contracts that were signed before 1990 also rolled over to the 1991-2007 period, which means that LTCs might have covered almost the entire gas consumption in Europe.

Also, two other important trends are worth noting in LTCs: (1) The share of pipeline gas contracts dominated the first two periods (before 1990 and 
Table 1 Long-term gas supply contracts in Europe. Source: Bloomberg Terminal \& Neumann et al. (2015)

\begin{tabular}{lllll}
\hline & Before 1990 & 1991-2007 & 2008-2014 & 2015-2018 \\
\hline Number of contracts & 31 & 121 & 28 & 18 \\
Total ACQ, billion cubic metres/year (bcm/y) & 109 & 292 & 98 & 54 \\
Average contract duration, years & 23 & 18 & 15 & 14 \\
Share of pipeline contracts & $68 \%$ & $53 \%$ & $50 \%$ & $22 \%$ \\
EU average gas consumption, bcm/y & $345^{\mathrm{a}}$ & 440 & 472 & 444 \\
Share of total ACQ in consumption & $32 \%$ & $66 \%$ & $21 \%$ & $12 \%$ \\
\hline
\end{tabular}

$A C Q$ annual contract quantity

a 1990 consumption

1991-2007), while the last two periods saw an uptake in liquefied natural gas (LNG) supply contracts; and (2) the number of LTCs as well as the average duration decreases over time. I will discuss these trends in detail.

Consistent with the transaction-cost framework, the rationale for setting up LTCs is to protect buyers and sellers from ex post opportunism that arises from the highly asset-specific, durable, and capital-intense investments involved in: (1) the development of upstream production, gas treatment and LNG facilities; (2) long-distance international pipelines and LNG vessels; and (3) national transmission and distribution systems at the local level. This protection takes the form of agreed-upon minimum payments to sellers irrespective of actual offtake by buyers: the so-called minimum "take-or-pay" (ToP) level.

Thus, the buyer takes volume risks, whereas the seller agrees to settle the transaction at a price that is (slightly) below the price of competing fuels, which are usually oil products. The subsequent change in contract price is pegged to a basket of oil products and other competing fuel prices at the 'burner tip' (final markets) ${ }^{1}$; therefore, the seller takes price risks since s/he does not control the pricing of gas and relies on the pricing dynamics of competing fuels. This arrangement ensures that gas stays competitive with other fuels in an environment in which there is no gas-togas competition.

Furthermore, the pricing in such agreements is used as a mechanism to divide the rent that is associated with producing, transporting, and marketing gas between sellers and buyers; on using LTCs to distribute the gains from trade between contracting parties, see Masten and Croker (1985); Crocker and Masten (1988); Mulherin (1986).

\footnotetext{
${ }^{1}$ It is worth noting that gas-to-oil price linkages were quite effective in introducing competition between gas and oil products and between upstream gas suppliers. For example, Asche et al. (2002) examined whether the German gas market was integrated in the period of 1990-1998: before the major gas market integration and liberalization processes. Their co-integration tests show that the different border prices for gas to Germany move proportionally over time, which indicates an integrated gas market. They also found that Russian gas prices are systematically lower than Dutch and Norwegian prices, which is explained by the value of flexibility and perceived political risks.
} 
Table 2 Evolution of the international gas trade: from LTCs to short-term and spot markets. Source: Author's own assessment

\begin{tabular}{llll}
\hline & 1970 s & 2000 & 2016 \\
\hline Number of sellers & 16 & 34 & 51 \\
Number of buyers & 18 & 56 & 81 \\
Asset Specificity & High & High/moderate & Moderate/low \\
Asset Intensity & High & High & high/moderate \\
Asset Durability & 20 -plus years & & \\
Transaction frequency & High & & \\
Uncertainty & High & & \\
Vertical coordination mechanism & Most transactions via vertical integration & Half of transactions \\
& and LTCs & & conducted on spot \\
& & & markets \\
\hline
\end{tabular}

Numbers of sellers and buyers (in brackets) are based on counts of gas-exporting and-importing countries that are provided by the International Energy Agency (IEA) in its 2017 Natural Gas Information report (IEA 2017)

As such, the emergence and evolution of the natural gas trade in Europe fits neatly with the transaction cost economics framework. Table 2 outlines the main characteristics of the industry with the use of transaction-cost economics terminology. We can see that the two most important factors that constitute the foundation of LTCs supporting gas trade and investment in Europe are: (1) industry structure (number of buyers and sellers); and (2) asset characteristics. The latter have changed dramatically over the past 20 years, and the rationale for and role of LTCs in the European gas trade have diminished significantly. I will discuss the reasons for this decline.

The international gas trade has expanded dramatically since the early 1970s, when the industry structure was balanced with a low number of gas-exporting andimporting countries (see Table 2: 16 sellers and 18 buyers). By 2000, these numbers had more than doubled to 34 gas exporters and 56 gas importers. By 2016, the market structure was dominated by buyers: The number of exporters had reached 51, while the number of buyers had increased to 81 (IEA 2017).

We could argue that, overall, the market has witnessed a dramatic increase in the total number of participants. Traditionally, the gas markets have been regional in nature, which reflects the large-scale infrastructure investments along the whole value chain and the capital requirements to build transport pipeline networks to supply gas to end-consumers. This means that the effective number of trading partners in each of the regional markets-North America, Europe, and Asia-is in fact substantially lower.

However, these regional markets have become increasingly linked by gas trade via seaborne routes, using LNG vessels to trade gas over greater distances. From the late 1960s until the mid-2000s, there was a general trend of cost reduction due to technological improvements across the whole LNG value chain (Stern 2006; Greaker and Sagen 2008). Coupled with demand uptake in remote consumption centres relative to production locations, this allowed LNG to emerge as one of the fastest-growing internationally traded commodities over 1960-2016, when annual 
growth in LNG exports averaged $14 \%$ per annum. ${ }^{2}$ Over this period, there was a proliferation of the number of LNG-exporting countries, starting with Algeria, the first LNG exporter: In 1975 there were only four exporters, whereas by 1995, this figure had reached eight, and by 2014, there were 20 LNG exporters (including re-exports from European countries to other markets).

Furthermore, and as I will discuss below, LNG contracts are generally smaller in terms of annual offtake quantity and shorter in duration than pipeline gas contracts. This suggests, among other things, that since it is more flexible in terms of transport mode, LNG trade is less asset-specific than trade via pipelines (see Table 1, for example: the average duration of LTCs and share of LNG/pipeline contracts in recent periods in Europe). Therefore, the uptake in LNG trade not only increased the effective number of trading partners but also introduced more flexibility to both sides of the market, thereby reducing the degree of specificity of international gas trade.

Europe has fully taken advantage of this development in the LNG trade. Table 3 outlines the evolution of European gas import capacity by LNG and pipelines.

Table 3 shows that in 1999, the European gas industry was dominated by a few extra-EU pipeline gas suppliers: Russia was the largest both in terms of reserves (BP 2018) and export capacity to Europe. It was an oligopolistic supply structure. However, in the period 1999-2016, European LNG import capacity expanded by 2.5 times (relative to the 1999 level) and accounted for $50 \%$ of total consumption (2016), while total pipeline import capacity grew only by $31 \%$ in the same time. This dramatic increase in LNG import capacity-coupled with an increase in the number of LNG exporters (and total export capacity) globally-allowed Europe to limit the potential market power of pipeline exporters: in particular, the potential market power of Russia/Gazprom. However, the increase in LNG import capacity alone might have had a limited effect without the liberalization process.

While the number of exporters and importers increased worldwide, market liberalization and the ability to tap into global LNG markets meant that the number of buyers and sellers also increased in European gas markets, which reflected trade in organised market exchanges (gas hubs or spot markets). The liberalization process began with the 1991 Gas Transit Directive and the subsequent legal battle between European antitrust authorities and major exporters to remove destination clauses from long-term pipeline and LNG import contracts (see below). This was followed by the first two energy packages (1998 and 2003) and then by the Third Energy Package (2009).

In the 1990s and early 2000s, the EU antitrust authorities were successful in negotiations with exporters to remove the destination clauses from long-term LNG and pipeline gas contracts. These clauses were seen as major impediments to market competition in Europe because they prohibited importers from reselling gas to other market geographies and segments.

\footnotetext{
2 Author's calculation based on Poten and Partners LNG trade database, accessed through the Bloomberg Terminal.
} 
Table 3 Breaking up the pipeline oligopoly in Europe: the role of LNG. Source: BP (2018) and IEA (2000, 2007, 2017); pipeline import capacity_author's own assessment based on various websites of export pipelines

\begin{tabular}{llll}
\hline & 1999 & 2006 & 2016 \\
\hline LNG import capacity: total (bcm) & 64.3 & 90.9 & 225.6 \\
Belgium & 5.5 & 5.5 & 9.5 \\
France & 17.9 & 17.9 & 36.2 \\
Greece & 0 & 1.4 & 5.2 \\
Italy & 3.5 & 3.5 & 15.9 \\
Portugal & 0 & 5.5 & 8 \\
Spain & 37.4 & 52.2 & 72.8 \\
UK & 0 & 4.9 & 55.2 \\
Lithuania & 0 & 0 & 4.2 \\
Netherlands & 0 & 0 & 12.7 \\
Poland & 0 & 0 & 5.3 \\
Sweden & 0 & 0 & 0.6 \\
Pipeline import capacity: total (bcm) & 321.2 & 332.2 & 421.2 \\
Russia & 175 & 175 & 230 \\
Norway & 104 & 104 & 130 \\
North Africa & 42.2 & 53.2 & 61.2 \\
EU consumption (bcm) & 460 & 512 & 449 \\
Share of LNG capacity in EU consumption & $14 \%$ & $18 \%$ & $50 \%$ \\
Share of pipeline capacity in EU consumption & $70 \%$ & $65 \%$ & $94 \%$ \\
LNG import capacity (relative to 1999) & $100 \%$ & $141 \%$ & $351 \%$ \\
Pipeline import capacity (relative to 1999) & $100 \%$ & $103 \%$ & $131 \%$ \\
Number of LNG exporters: countries (export capacity, & $11(145)$ & $13(254)$ & $20(465)$ \\
bcm) & & & \\
\hline & & & \\
\hline
\end{tabular}

The antitrust authorities then targeted the largest European gas importers-such as GDF Suez, ENI, and E.ON-expressing concern that these companies used exclusive access to gas transportation facilities effectively to limit competition in their market areas. As a result, these companies reached agreements with the competition authorities to reduce their long-term capacity reservations-capacity release programmes were established by GDF Suez, Eni, and E.ON-to allow new suppliers to enter the market (European Commission (EC) 2009a, b, 2010).

At the same time, national antitrust authorities also investigated the state of market competition further downstream, including LTCs between second-tier suppliers and larger importers. For example, Germany's national antitrust authority (BKartA) introduced limitations on contract duration and supply quotas for a period of 3 years (2007-2010) to enable more downstream competition by allowing second-tier buyers to switch suppliers (European Competition Network 2010).

As a result of this regulatory intervention, many second-tier suppliers such as power generators and local distribution companies became part of the gas value chain. 
The pricing of gas in LTCs has also undergone substantial changes. The liberalisation of gas markets in Europe-coupled with: (1) increased investment in LNG import terminals to benefit from global LNG trade (see Table 3); and (2) low gas demand following the economic crisis of 2008 and increased inter-fuel competition (e.g., the uptake of coal and renewables in European electricity generation)-forced European buyers to renegotiate pricing mechanisms in their traditional contracts with pipeline suppliers. As such, since around 2010, a pricing system has emerged in Europe that is based on long-term oil-indexed contracts and market prices that are settled in trading hubs (the National Balancing Point (NBP) in the UK and the Title Transfer Facility (TTF) Virtual Trading Point in Continental Europe).

Because of these regulatory interventions and changes in market dynamics, it is estimated that the overall volume of spot gas trade in Europe stood at $43 \%$ in 2013 (Société Générale 2013) and rose to 66\% in 2016 (International Gas Union 2017), with the remainder being undertaken via traditional oil-indexed long-term bilateral contracts and other pricing mechanisms.

Thus, the organisational form of the gas trade in Europe has changed quite dramatically, with increasing trade volumes being transacted through organised markets rather than being dominated by bilateral contracts, as used to be the case. This point is also reinforced by the fact that the emergence of spot and futures markets for gas trade greatly reduces the transaction costs of long-term contracting because: (1) contracts are standardised and hence easily transferable (traded); and (2) prices are set transparently via multiple trades rather than costly bilateral (re)negotiations; for a detailed discussion on this point, see Doane and Spulber (1994).

Furthermore, the industry structure in Europe developed in response to changes in regulatory developments that are aimed at creating a single market for gas in Europe as well as to the degree of asset specificity involved in gas trade.

In the early days of the European gas industry, buyers and sellers relied on very large LTCs (in terms of offtake quantities) (see Table 1) to develop gas fields and to finance long-distance, cross-border pipelines and transmission and distribution systems. These LTCs essentially covered at least two parts of the gas value chain: (1) production; and (2) transportation. On the buying side, buyers were vertically integrated (usually state-owned) companies, which helped them develop and control national transmission and local distribution systems as well as gas sales and marketing. On the selling side, producers were responsible for developing gas fields and the associated infrastructure as well as large-scale, long-distance pipelines that usually crossed the borders of more than one country. This is particularly true for Russian gas supplies: These pipelines sometimes crossed more than three countries before reaching delivery points in Europe.

Thus, the traditional model — 'from wellhead to burner tip'-was effectively broken by EU legislation that was introduced to increase competition and market integration at the midstream and downstream levels of the European gas markets. Among other fundamental changes that were brought about by this legislation, one particular structural shift was the so-called 'unbundling' or breaking up of vertically integrated utility companies on the buy side, which could no longer control infrastructure components of the gas business. Transmission and distribution within Europe-which were previously seen as natural monopolies—are now managed by 
independent companies and are subject to regulation in terms of service quality and tariff setting.

Thus, on the buy side at least, the transportation component became a separate regulated business activity and was no longer part of the chain of traditional LTCs between producers and buyers. A second structural shift was the introduction of third-party access to transport infrastructure in Europe: Should there be demand for access to transport capacity, the independent operator should grant such access subject to technical and other requirements that are transparent to all market participants. Together, these two changes meant that gas transportation infrastructure in Europe no longer posed a high risk of opportunism because these regulations essentially reduced the degree of asset-specificity that was involved in gas transactions between buyers and sellers. Although investment in transmission and distribution is still durable and capital intensive - albeit less so than it used to be-it is now less risky due to these sectors being regulated monopolies.

In addition to changes in how gas transport infrastructure is governed in Europe, pipelines and LNG as modes of transporting gas have been subject to substantial cost reductions - or reduced capital intensiveness-due to technological improvements. For a detailed discussion of cost reductions in pipeline and LNG transport, see, for example, papers by Cornot-Gandolphe et al. (2003) and Jensen (2003). All else being equal, reduction in capital intensiveness leads to lower risks and potential losses that arise from the ex post hold-up problem. The reduced risk of holdups together with the changes in organisational form for the investment in and management of transport assets in Europe means that there is no longer a rationale for including these assets in traditional long-term purchase contracts between buyers and sellers, as was the case when the industry began to develop in the 1960s and 1970s.

On the selling side, production facilities — such as gas wells and treatment facilities - are not highly asset-specific per se and can be used to produce gas for sales to any buyer, or market-provided transportation to these markets and buyers is already established. Thus, the high asset specificity in the gas industry lies simply in transportation assets (for a detailed discussion of this point, see Doane and Spulber 1994); and in Europe, a part of these assets is now under regulation and poses a low risk of hold-ups.

The only remaining issue is the long-distance pipelines that connect producers to European border points - most of which have already been developed as part of the first wave of LTCs (see Table 1) between major producers (Russia, Norway, and Algeria) and European buyers. I exclude from this discussion the issue of the transit monopoly and associated risks of supplying Russian gas to Europe, which is beyond the scope of this paper. However, the perceived high monopoly power of transit countries and the associated risks of rent expropriation by such transit countries motivates producers, such as Russia, to seek new capacity that it can control via 
LTCs or some other form of vertical integration. ${ }^{3}$ Nonetheless, going forward, it is expected that the need for such 'transit-bypass' transport capacity will be minimal relative to the overall potential trade volume between Russia and Europe. ${ }^{4}$

This suggests that the role of LTCs in European gas trading will diminish substantially in the coming decades due to a decrease in: (1) capital intensiveness; and (2) the level of asset-specificity that is associated with changes in the regulatory regime that governs the investment in and management of transport assets in Europe in particular and the liberalization process in general as well as higher volumes of LNG in overall gas trade (LNG is a more flexible mode of trade and is hence less asset-specific).

Next, I discuss some empirical and theoretical studies on the changing nature of the gas trade in Europe and the implications for LTCs.

\section{Effects of Industry Liberalization on the Gas Trade in Europe}

The theoretical literature on LTCs in the gas industry outlines the conditions under which markets or LTCs dominate. For example, Doane and Spulber (1994) showed that changes in the regulatory framework towards increased competition through unbundling, third-party access, and the regulation of pipelines in the US gas industry decreased transaction costs between buyers and sellers, which thereby enhanced spot trade. As discussed, Doane and Spulber also stressed that the reduction in transaction costs comes from the fact that third-party access and the regulation of pipelines means that purchase contracts do not need to be tied to a specific pipeline and producer-buyer pair.

Brito and Hartley (2002) applied a microeconomic (search) model and showed that the length of long-term LNG contracts was likely to diminish with: (1) the decreasing capital-intensiveness of the assets involved in LNG transactions; (2) the increasing cost of capital (discount rate); and (3) a larger number of players in the market (suppliers and buyers). Brito and Hartley (2007) and Hartley (2015) also suggest that the role of long-term LNG contracts will diminish as spot market liquidity increases. In particular, Hartley (2015) uses a microeconomic model to show the link between increased LNG market liquidity, greater volumes, and destination flexibility in contracts and increased short-term and spot market trades, which reinforce increases in market liquidity. ${ }^{5}$

\footnotetext{
${ }^{3}$ For example, the Belarus transit system, which is co-owned by Russia and Belarus, or the Blue Stream and Nord Stream pipeline investments that helped Russia reduce its dependence on traditional transit routes were carried out as joint ventures with Russia's major gas buyers in Europe.

4 Abstracting away from the politics of pipeline gas sales to Europe in light of the recent geopolitical tensions between Russia, Ukraine, and Europe, the need for new bypass capacity is minimal since Russia has already invested in alternative transport capacity that bypasses Ukraine substantially. Similarly, to completely circumvent Ukraine, Russia would require another transport route with roughly 50-60 bcm/ year, which is about $30 \%$ of its expected total annual contract volume to Europe in the next two decades.

5 This theoretical prediction is in line with the view of some gas market analysts in Europe, who state that if spot trade exceeds $50 \%$ of all traded volume, the move towards complete spot trade is irreversible; see, e.g., presentations and speeches by Thierry Bros, a researcher from Société Générale.
} 
Parsons (1989) obtained similar findings by applying an auction model to find the 'strategic' value ${ }^{6}$ of long-term gas contracts that are signed by producers such as Russia, Norway, and Canada. Parsons found that the value of such contracts for the producer diminishes as: (1) the number of wholesale buyers increases; and (2) the cost structure decreases prior to spot sales (capital intensiveness).

Other empirical work analyses the impact of the changing structure and asset specificity of the European gas industry on LTCs and on contract duration in particular: For example, von Hirschhausen and Neumann (2008) conducted an econometric analysis of over 300 LTCs and found an inverse relationship between contract duration and: (1) deliveries to the restructured markets of the US and UK and to the post-1998 markets of Continental Europe (i.e., after the first energy package); (2) contracts not linked to substantial new investment; and (3) those signed by new market entrants. All else being equal, these findings suggest that as gas markets in Europe are liberalized and mature further-with no need for substantial investment in infrastructure - and market entry increases, the duration of LTCs will decrease.

Ruester (2009) conducted a similar econometric analysis of 224 LNG contracts, finding that: (1) as asset specificity decreases, so does the duration of LNG contracts; (2) post-2000 LNG contracts are generally shorter than those signed before that period; and (3) in the presence of high price uncertainty, contract duration tends to be lower. The last two conclusions are important because: (1) post-2000 LNG contracts are shorter because of the substantial cost reductions that were achieved across the whole LNG value chain; and (2) when prices are uncertain, the benefits of LTCs diminish due to potential profits from arbitrage, as prices tend to fluctuate more, while the cost of holding such contracts becomes higher in the sense of their 'incompleteness'. This is especially true in the examples of contract renegotiations between European buyers and sellers post-2008. Chyong (2015) obtained similar results: Market liberalization in Europe-together with a general reduction in the capital intensiveness of infrastructure assets - has indeed reduced the role of LTCs: specifically, by negatively affecting the duration of such contracts.

The literature points to the fact that European gas markets have been moving away from rigid bilateral long-term contracts to shorter-term and spot-market trading arrangements. Indeed, Miriello and Polo (2015) argued that the gas wholesale trade in Europe was initially developed to cope with the physical balancing needs of market participants, and as these become more liquid, the balancing markets became a second source of gas procurement.

Finally, Miriello and Polo (2015) noted that-to manage price risks-financial instruments and forward/futures markets also gradually developed. In line with findings from the empirical institutional economics literature-in particular those by von Hirschhausen and Neumann (2008) and Miriello and Polo (2015), in examining the institutional arrangements of gas market regulation in selected European markets, noted that the UK and the Netherlands have been leading the process of market liberalization, while Germany and Italy are constrained by limited supply and hence

\footnotetext{
${ }^{6}$ Defined in Parsons (1989) as the difference between the value of the commodity in the LTC and the sales price in a more competitive market.
} 
Table 4 European gas prices: 2013-2016 (Eur/MWh). Source: ACER's annual report on the results of monitoring the internal electricity and natural gas markets for 2013-2016 years. Available for download from ACER's website: https://acer.europ a.eu/en/Pages/default.aspx and Thomson Reuters for oilindexed contract prices

\begin{tabular}{lrrrr}
\hline & 2013 & 2014 & 2015 & 2016 \\
\hline Max price in the sample & 37.5 & 32.0 & 27.9 & 19.5 \\
Min price in the sample & 27.0 & 21.9 & 21.0 & 14.1 \\
Mean price in the sample & 30.2 & 26.2 & 23.2 & 16.6 \\
Spread: TTF_mean & 3.0 & 2.5 & 2.2 & 1.1 \\
Spread: TTF_min & 0.2 & 1.8 & 0.0 & 1.4 \\
Spread: TTF_max & 10.3 & 8.3 & 6.9 & 4.0 \\
Spread: max-min & 10.5 & 10.1 & 6.9 & 5.4 \\
Spread: TTF_oil-indexed & 9.9 & 10.8 & 6.9 & 4.6 \\
contract prices & & & & \\
\hline
\end{tabular}

TTF the title transfer facility: a virtual trading point for natural gas in the Netherlands. MAX, MIN, and MEAN are taken for a sample of annual prices for $26 \mathrm{EU}$ countries; these prices were taken from the ACER gas market monitoring reports https://acer.europa.eu/en/Pages /default.aspx. Reported spreads are absolute values

lag behind the former two markets in terms of developing competitive wholesale markets.

As Northwest European (NWE) wholesale gas trading picked up after the liberalization processes, so did the ex post empirical analyses of gas price convergence. Siliverstovs et al. (2005) and Neumann (2009) confirm the importance of the LNG trade in fostering global gas-on-gas competition and price integration-particularly the European and North American spot prices. Neumann et al. (2006) analysed price convergence between two traded gas hubs in Northwest Europe in 2005 and found that after the construction of a bi-directional pipeline that connected the UK and Belgium, the prices in those two markets converged.

Further, liberalization on the European continent does seem to be working. Note that the end of their time series analysis was 2005: before the Third Energy Package $^{7}$ took place. More recent empirical work that analyses price correlation and convergence for different European markets all suggest that the EU integration policies have been successful: Major gas markets in Europe were fully integrated by 2013; see, e.g., Harmsen and Jepma (2011), Neumann and Cullman (2012), Growitsch et al. (2013), Asche et al. (2013) and Petrovich (2013).

Indeed, EC (2011) concluded in its report on progress in creating the internal gas and electricity market for 2009-2010 that significant barriers to open integrated and competitive markets in electricity and gas remain. However, by 2013, ACER (2014) reported increased gas wholesale price convergence across the EU, and the trends towards price convergence were observed further in 2014-2016 ${ }^{8}$ (Table 4). This

\footnotetext{
7 a legislative package for an internal gas and electricity market in the European Union. Its purpose is to further open the gas and electricity markets in the European Union. The package was proposed by the European Commission in September 2007 and adopted by the European Parliament and the Council of the European Union in July 2009. It entered into force on 3 September 2009.

8 See ACER's Annual Report on the Results of Monitoring the Internal Electricity and Natural Gas Markets for 2013-2016 years. Available for download from ACER's website: https://acer.europa.eu/en/Pages /default.aspx.
} 


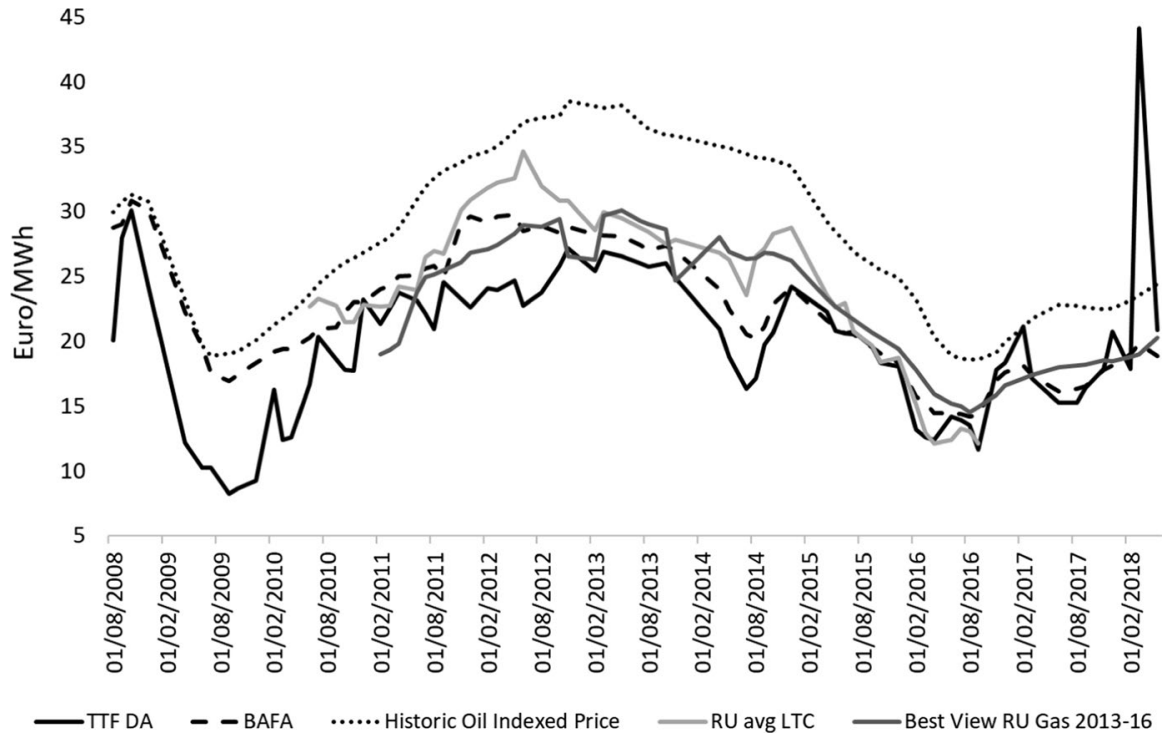

Fig. 1 Evolution of spot and oil-indexed gas prices in Europe. Notes: TTF DA: TTF day-ahead price assessment reported by Thomson Reuters (access via Eikon Terminal); RU avg LTC is an average actual monthly price of Russian LTC gas sold at the German border as reported by Ministry of Economic Development of Russian Federation. From October 2016, the source stopped updating this price. The 'RU best view' gives a view of what prices on these contracts would have looked like against current prices. The 'RU best view' is Thomson Reuters' view of the level of contractual prices between Gazprom and the large western European buyers in the general period 2013-2016. This combines an element of hub indexation $(15 \%)$ with a further discount that is applied to improve competitiveness against hub prices. The historic oil-indexed price is calibrated using historic BAFA (average gas import) prices at the German border over a period when all gas coming into Germany was oil-indexed (pre-2008). It is used in this chart to predict the level at which these contracts would be now against hub prices, even though an accepted view by the European gas industry is that oil indexation is no longer relevant for pricing gas in western Europe. The formula of the oil-indexed price is given as: oil-indexed $=\mathrm{B} 0+\mathrm{B} 1 *$ Average oil price where Average oil price is the average of gas oil and fuel oil prices. The oil prices are averaged for between 3 and 9 months and lagged by 0 to 3 months to optimise the model fit. Source: Own illustration based on data from Thomson Reuters accessed through Eikon Terminal

price convergence trend was observed not just for traded markets, but also between different 'immature' traded markets in which gas prices are predominantly set by bilateral LTCs (for discussions of pricing in such LTCs, see Sect. 2).

The single most important factor that allowed for such a price convergencenot just between traded hubs as found by the cited econometric analyses but also between hubs and immature markets-is the slump in gas demand in Europe relative to contracted volume between midstream and upstream companies and the abundance of LNG volumes in the period from 2009 to 2014. These macro and upstream trends allowed traditional oil-linked LTCs in Europe to be renegotiated and brought 
in line with market traded prices of Northwestern Europe (see Fig. 1). ${ }^{9}$ Koenig (2012) and Chyong and Kazmin (2016) have shown the importance of LNG imports in Europe in breaking up the structural linkages between gas spot and oil-linked gas prices. Figure 1 suggests that since about mid-2009, the oil-indexed contract prices (BAFA ${ }^{10}$ and Russian average contract prices delivered to Germany) began to diverge from their theoretical value (historic oil-indexed price, Fig. 1). Moreover, the oil-indexed contract prices closely track the spot prices of NWE markets: TTF.

On the welfare benefits of having a single market for gas, the same report by Agency for the Cooperation of Energy Regulators (ACER) (2014) estimated that due to lack of gas market integration, potential annual gas wholesale gross welfare losses amounted to 7 bn euros (ACER put this figure at 11 bn euros for 2012). The decrease in welfare losses between these 2 years was mainly due to LTC renegotiations. A more important benefit (that is perhaps less amenable to quantification) that a single gas market may bring to Europe is the minimisation of political consequences of price differences that is observed between different member states (see, e.g., Noel 2009).

Finally, it is worth noting that although price convergence between European gas markets is a sign of a well-integrated pan-European wholesale market for gas, there are great price differences between Europe and another large and the most competitive gas market: the United States (see, e.g., Makholm 2015). Makholm (2012, 2015) outlined in great detail the differences in institutional arrangements of gas markets in Europe and in the US (and in other jurisdictions). He concluded that Europe's chosen market design for gas (which follows market design for its electricity sector) has impeded the development of competitively priced gas. I turn to this question in Sect. 4.

To summarise, the theoretical literature and empirical evidence suggest that the European gas industry has changed dramatically in the last 20 years in response to regulatory, technological, and industrial dynamics. The industry has gradually transformed from domination by state-owned monopolies and rigid bilateral contracts to a more competitive market.

However, there are still impediments to the completion of the project of creating a single market for gas in Europe, which I summarise in our next section.

\section{European Gas Markets: Looking Forward}

In a perfectly competitive and integrated market, the 'relative law of one price' should be observed: Prices for a homogenous commodity, such as natural gas, across different locations should only differ by transaction costs: e.g., transport costs of moving gas from one location to another. The most recent gas trade data that were

\footnotetext{
${ }^{9}$ For example, in 2016, Russia renegotiated a number of its long-term contracts with several big buyers, which moved the price of Russian LTC close to the spot level.

10 Germany's Federal Office for Economic Affairs and Export Control.
} 


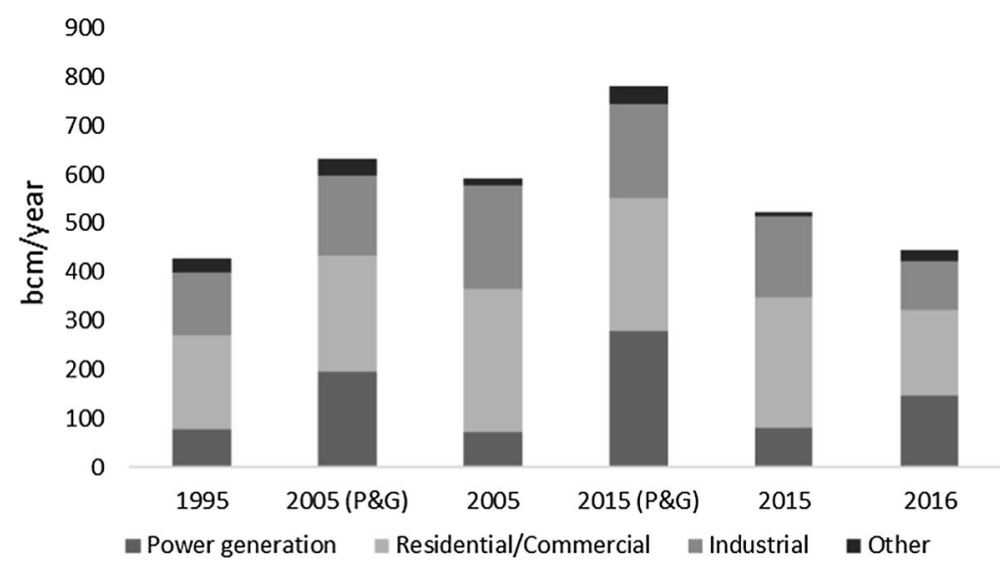

Fig. 2 Realised and forecasted gas demand in Europe. Note: P\&G means Purvin and Gerts 1998 gas demand forecast for the year of 2015. Source: 1995-2015 Period was reproduced based on Gazprom Export: http://www.gazpromexport.ru/en/presscenter/speech/; 2016 data from Eurostat

reported by ACER (2017) suggest that price differentials between most traded hubs in Europe were even below transport tariffs.

Given that price differences between traded and non-traded hubs have been moving closer due to the elimination of oil-linkages in the traditional LTCs (see Sect. 3), the divergence of prices between different locations could be dictated largely by either transport tariffs and/or non-trade barriers (lack of implementation and/or derogation from certain rules of the Third Energy package, for example). The latter are monitored by the European authorities and subject to negotiations between the Commission and the national authorities of each member states. Transport tariffs have gained much of the attention in the recent debate about the future of gas market design in Europe (see, e.g., the EC's commissioned work Study on Quo vadis gas market regulatory framework ${ }^{11}$ ).

The Third Energy Package stipulates, among other things, the creation of entryexit $(\mathrm{E} / \mathrm{E})$ zones that are managed by an independent transmission system operator (TSO) and that shippers can book entry and exit capacity rights independently, effectively creating gas transport through zones instead of contractual paths. Each of these transport zones is further supported by a virtual trading point (hubs) where gas can be freely traded among shippers who have entry and/or exit rights. Geographically, each of these zones roughly corresponds to a national market of a EU member state. Transmission tariffs for the entry and exit capacities are designed for full (sunk) cost recovery: The tariffs depend on the utilisation of the entire gas network of each transport zone.

Thus, a principal reason that location price spreads between different European gas hubs are below cross-border transport tariffs is because suppliers and shippers

\footnotetext{
${ }^{11}$ See EC DG Energy website: https://ec.europa.eu/energy/en/studies/study-quo-vadis-gas-market-regul atory-frameworks.
} 
hold long-term capacity bookings and regard them as sunk costs. Therefore, existing cross-border gas trade in Europe is largely influenced by the short-run marginal cost of moving gas between hubs. In the process of liberalization and unbundling network activities from competitive activities, national authorities and incumbent gas suppliers have agreed to book on a long-term basis the majority of entry and exit capacities in their respective transport zones to underwrite the utilisation of their respective gas transmission networks.

However, given that the European gas network and supply structures were built largely based on the view of expanding gas demand in Europe (see Fig. 2; Table 1), once these long-term transport capacity bookings expire (mid-2020s), locational price spreads could diverge to reflect full cost-recovery transport tariffs between transport zones.

Thus, given that gas demand in Europe is likely to stay flat (or even fall) relative to the overall size of the transmission network, the tariffs for using the transport network will increase. This trend will be exacerbated should transmission system operators (TSOs) implement their announced investment plans for the period 2015-2025. It is expected that the annual tariff increase should be $+0.8 \%$ in the gas sector in Europe (BearingPoint \& Microeconomix 2015). The cumulative increase in some member states could be as high as 39\% for the period 2015-2025. The majority of expected investment in the gas network is driven by the security of supply concerns in Central, Eastern, and Southern Europe.

Therefore, the future of the European gas market integration to a large extent (if measured by price differentials between market/transport zones) depends on the effectiveness of the current regulatory regime in ensuring cost-reflective tariff setting that considers falling gas demand and the inherited large gas transport networks.

Possible high locational price differences may motivate 'tailored' national policy responses when the European authorities try to 'harmonise' national policies (which has been a substantial effort by the authorities since the enactment of the Third Energy Package). The following example will highlight the importance of transport tariffs and shed light on a general problem of defining gas transport market using entry-exit zones:

There has been a persistently high locational price spread between Northwest European hubs and Italy, which reflects high transport tariffs between the two market regions. According to the recent ACER (2017) report, the locational price spread between PSV (the Italian hub price) and TTF (the Northwest European hub price) is about $€ 2 / \mathrm{MWh}$, or $€ 1.4 \mathrm{bn}$ in loss of annual welfare for Italy given its current demand level. ${ }^{12}$

A solution to reduce this high price spread has been put forth by the Italian Ministry of Economic Development in its new energy strategy (June $2017^{13}$ ). It involves the purchase by the Italian TSO of all transport capacity from TTF to PSV on a

\footnotetext{
${ }^{12}$ For comparison, the price spread between TTF and the German virtual trading point NCG is ca. $€ 0.2-$ $0.3 / \mathrm{MWh}$

${ }^{13} \mathrm{http} / / /$ dgsaie.mise.gov.it/sen/Strategia_Energetica_Nazionale_2017_-_documento_di_consultazione. pdf.
} 
long-term basis and reselling these capacities to market participants at a short-run marginal cost; any gap between the cost of buying all of this capacity and the revenue that is received will be socialised across all Italian gas consumers. The primary reason for this solution is to avoid 'tariff pancaking' ${ }^{14}$ and to facilitate cross-border gas trade between the marginal source of gas for Italy, which is TTF, and its wholesale market.

There are other examples in which cross-border transport tariffs reach as high as $50 \%$ of wholesale gas commodity prices (see, e.g., REKK 2016). These high crossborder tariffs are predominantly in Central, Eastern, and Southeastern European (CEE/SEE) countries (see, e.g., REKK 2016; ACER 2017), where concern about the security of supply is high on the political agenda; and if any investment in gas infrastructure is taking place, it will be based on security-of-supply concerns.

Thus, the risk of divergence of prices between NWE and CEE/SEE markets in the future is real, with likely political consequences, as Noel (2009) pointed out. Chyong (2017) ${ }^{15}$ demonstrated this issue with some quantitative results: In the CEE/ SEE and the Baltic gas markets, should Gazprom (a dominant supplier) change its pricing strategy to lock out competition from LNG, then the gas infrastructure that was initially built with security of supply in mind will see a substantial reduction in its utilisation. This implies greater cross-border transport tariffs and hence possible disintegration of these markets from the rest of Europe (Chyong 2017).

The issue of transport tariffs and the way that infrastructure costs should be recovered will play ever-more important roles-not least because of price divergence, but also because this will dictate the pricing strategy of dominant suppliers in those markets. This is because, from the economic point of view, 'tariff pancaking' distorts competition and cross-border trade by increasing wholesale price differentials, which allows a costlier marginal source to meet demand. Put differently: A 'clever' Stackelberg supplier will price its gas just slightly cheaper than the most expensive supply source plus the transport tariff into that market. ${ }^{16}$ 'Tariff pancaking' also reduces the utilisation of existing infrastructure and could lead to a "death spiral": A lower utilisation rate will increase tariffs (average cost) further. This is inefficient when the average cost is increasing relative to short-run marginal costs.

Furthermore, the nature of transport tariff setting in the existing entry-exit system is such that it may be influenced by the political economy considerations of each member states and the TSOs that manage their respective transport zones. This is especially pronounced in an oversized gas system and/or in the context of a need

\footnotetext{
14 Tariff pancaking happens when natural gas has to cross multiple market zones and is charged with successive tariffs for each zone crossed. The pancaking means that multiple tariffs are accumulated and a supply source which must cross several zones become too expensive.

15 http://www.eprg.group.cam.ac.uk/wp-content/uploads/2017/05/An-Assessment-of-Gazproms-commi tments_CHYONG.pdf.

${ }^{16}$ In the gas industry terminology, the marginal supplier will price its gas in the market according to the netback basis: Its price is just slightly lower than the hub price (spot price) plus transport cost from the hub back to the market.
} 
to invest in the security of supply infrastructure. The current network codes ${ }^{17}$ allow much flexibility for each member states and their respective TSOs to set transport tariffs. With a large entry-exit system, there are far too many degrees of freedom in setting cost-reflective tariffs.

Thus, although the price differentials between traded hubs and between traded hubs and other markets (such as the markets of Central, Eastern, and Southeastern Europe) have narrowed dramatically in the last 5 years (see Sect. 3), location price spreads might widen again in the future. In the past, such high location price differences between NWE and CEE/SEE were predominantly due to discrepancies between hub-based (NWE) and high oil-linked (CEE/SEE) prices as well as supply structure (see Agency for the Cooperation of Energy Regulators (ACER) 2014). Going forward, locational price spreads could to a large extent be dictated by regulatory measures, policies around security of supply, cost recovery, and tariff structures for each of transport zones in Europe.

\section{Conclusions}

Since the enactment of the 1991 gas transit directive and subsequent energy directives and packages, the wholesale gas market in Europe is functioning as one would expect from a competitive and transparent commodity market. The move-which is still ongoing - towards a single market for gas has allowed European gas consumers to benefit from transparently set market-based wholesale prices-as well as from competitive pressures from all suppliers in Europe, which has mitigated potential market power in captive gas markets, especially those in Central, Eastern and Southern Europe. Structural changes in both the upstream and the downstream side of the European gas markets - coupled with regulatory changes - allowed a smooth transition from a gas system that relied on rigid bilateral LTCs to a healthy and competitive wholesale gas market in Europe.

However, as the gas market in Europe matures and with the advent of renewable energy generation in the electricity sector and overall decarbonisation of the energy sector in Europe, the gas market and its current regulatory regime face a number of challenges. Addressing these challenges may require the updating of the current market design and possibly drastic reforms of tariff-setting for the gas transport market. A more general question that European authorities may wish to consider is whether the existing market institutions can ensure competitive entry of new sources of gas supplies deep into the land-locked markets of Central, Eastern, and Southern Europe.

Despite the challenges ahead, the overall lesson to be learned from Europe is that the process of creating a single market for gas was positive; it has created net benefits to Europe in the form of price convergence, transparency, and the minimisation

\footnotetext{
17 Set of EU-wide rules governing all cross-border gas transactions. In particular these are (1) Interoperability and Data Exchange Rules, (2) balancing, (3) capacity allocation mechanism, (4) congestion management procedures, and (5) transmission tariff structures.
} 
of political consequences of possible market segmentation and disintegration. But the 'devil is in the details'; and hence, applying the European gas market liberalization experience to another context requires a deep understanding of socio-political and local market conditions.

Open Access This article is distributed under the terms of the Creative Commons Attribution 4.0 International License (http://creativecommons.org/licenses/by/4.0/), which permits unrestricted use, distribution, and reproduction in any medium, provided you give appropriate credit to the original author(s) and the source, provide a link to the Creative Commons license, and indicate if changes were made.

\section{References}

ACER. (2017). Annual report on the results of monitoring the internal electricity and natural gas markets in 2016. https://acer.europa.eu/Official_documents/Publications/Pages/Publication.aspx. Accessed May 2018.

Agency for the Cooperation of Energy Regulators (ACER). (2014). Annual report on the results of monitoring the internal electricity and natural gas markets in 2013. https://acer.europa.eu/Offic ial_documents/Publications/Pages/Publication.aspx. Accessed May 2018.

Asche, F., Misund, B., \& Sikveland, M. (2013). The relationship between spot and contract gas prices in Europe. Energy Economics, 38(2013), 212-217. https://doi.org/10.1016/j.eneco.2013.02.010.

Asche, F., Osmundsen, P., \& Tveteras, R. (2002). European market integration for gas? Volume flexibility and political risk. Energy Economics, 24, 249-265.

BearingPoint \& Microeconomix. (2015). "Study on comparative review of investment conditions for electricity and gas transmission system operators (TSOs) in the EU” for DG ENER. Available at: https ://publications.europa.eu/en/publication-detail/-/publication/4f2cc6a5-b8f9-11e5-8d3c-01aa75ed71 a1. Accessed Feb 2019.

BP. (2018). Statistical review of world energy-2018. https://www.bp.com/en/global/corporate/energ y-economics/statistical-review-of-world-energy.html. Accessed May 2018.

Brito, D., \& Hartley, P. (2002). Evolution of the international LNG market. Center for Energy Studies. http://bakerinstitute.org/files/2675/. Accessed 7 May 2015.

Brito, D. L., \& Hartley, P. R. (2007). Expectations and the evolving world gas market. The Energy Journal, 28(1), 1-24.

Chyong, C. K. (2015). Market and long-term contracts: The case of Russian gas suppliers to Europe. EPRG working paper series N1524.

Chyong, C. K. (2017). An assessment of Gazprom's proposed commitments concerning central and eastern European gas markets using a global gas market simulation model. EPRG research comment. http://www.eprg.group.cam.ac.uk/wp-content/uploads/2017/05/An-Assessment-of-Gazpromscommitments_CHYONG.pdf. Accessed May 2018.

Chyong, C. K., \& Kazmin, R. (2016). The economics of global LNG trade: The case of Atlantic and Pacific inter-basin arbitrage in 2010-2014. EPRG working paper series N1602.

Coase, R. H. (1937). The nature of the firm. Economica, 4(16), 386-405.

Coase, R. (1972). Industrial organization: A proposal for research. In V. R. Fuchs (Ed.), Economic research: Retrospect and prospect. Policy issues and research opportunities in industrial organization (Vol. 3, pp. 59-73). New York: National Bureau of Economic Research.

Cornot-Gandolphe, S., Appert, O., Dickel, R., Chabrelie, M.-F., \& Rojey, A. (2003). The challenges of further cost reductions for new supply options (pipeline, LNG, GTL). In Paper presented at 22nd world gas conference 1-5 June 2003, Tokyo, Japan. http://www.dma.dk/themes/LNGinfrastructu reproject/Documents/Infrastructure/IEA-The $\% 20$ challenges $\% 20$ of $\% 20$ further $\% 20 \operatorname{cost} \% 20 \mathrm{red}$ \%20new\%20supply\%20options.pdf. Accessed 7 June 2015.

Crocker, K. J., \& Masten, S. E. (1988). Mitigating contractual hazards: Unilateral options and contract length. Rand Journal of Economics, 19(3), 327-343.

Doane, M., \& Spulber, D. (1994). Open access and the evolution of the U.S. spot market for natural gas. Journal of Law and Economics, 37(2), 477-517. https://doi.org/10.1086/467321. 
EC. (2009b). Antitrust: Commission welcomes E.ON proposals to increase competition in German gas market. Brussels. http://europa.eu/rapid/press-release_MEMO-09-567_en.htm?locale=en. Accessed 10 July 2010.

EC. (2010). Commission welcomes ENI's structural remedies proposal to increase competition in the Italian gas market. Brussels. http://europa.eu/rapid/press-release_MEMO-10-29_en.htm?locale=en. Accessed 10 July 2010.

EC. (2011). 2009-2010 Report on progress in creating the internal gas and electricity market. Commission staff working document. https://ec.europa.eu/energy/sites/ener/files/documents/20100609_inter nal_market_report_2009_2010.pdf. Accessed May 2018.

Energy Charter Secretariat. (2007). Putting a price on energy: International pricing mechanisms for oil and gas. Energy charter secretariat report. http://www.energycharter.org/fileadmin/DocumentsM edia/Thematic/Oil_and_Gas_Pricing_2007_en.pdf. Accessed 10 February 2009.

European Commission (EC). (2009a). Antitrust: Commission accepts commitments by GDF Suez to boost competition in French gas market. Brussels. http://europa.eu/rapid/press-release_IP-09-1872_ en.htm. Accessed 10 July 2010.

European Competition Network (ECN). (2010). Germany: Positive development in the gas distribution sector: No need to prohibit long-term gas supply contracts in Germany any more. In ECN brief 04/2010. http://ec.europa.eu/competition/ecn/brief/04_2010/brief_04_2010.pdf. Accessed May 2018.

Goldberg, V. P. (1976). Regulation and administered contracts. Bell Journal of Economics, 7(2), 426-448.

Goldberg, V. P., \& Erickson, J. R. (1987). Quantity and price adjustment in long-term contracts: A case study of petroleum coke. Journal of Law and Economics, 30(2), 369-398. https://doi. org/10.1086/467141.

Greaker, M., \& Sagen, E. (2008). Explaining experience curves for new energy technologies: A case study of liquefied natural gas. Energy Economics, 30(6), 2899-2911.

Growitsch, C., Stronzik, M., \& Nepal, R. (2013). Price convergence and information efficiency in German natural gas markets. German Economic Review, 16, 87-103. https://doi.org/10.1111/geer.12034.

Harmsen, R., \& Jepma, C. (2011). North west European gas market: Integrated already. European Energy Review, 27, 15-24.

Hartley, P. R. (2015). The future of long-term LNG contracts. The Energy Journal, 36(3).

International Energy Agency (IEA). (2000). Natural gas information 2000. Paris: OECD/IEA.

International Energy Agency (IEA). (2007). Natural gas information 2007. Paris: OECD/IEA.

International Energy Agency (IEA). (2017). Natural gas information 2017. Paris: OECD/IEA.

International Gas Union (IGU). (2017). Wholesale gas price survey, 2017 edition: A global review of price formation mechanisms 2005-2016. IGU report.

Jensen, J. (2003). The LNG revolution. The Energy Journal, 24(2), 1-45.

Joskow, P. (1985). Vertical integration and long-term contracts: The case of coal-burning electric generating plants. Journal of Law Economics and Organization, 1(1), 33-80.

Klein, B. (1980). Transaction cost determinants of 'unfair' contractual relations. American Economic Review, 70(2), 356-362.

Klein, B., Crawford, R., \& Alchian, A. (1978). Vertical integration, appropriable rents and the competitive contracting process. Journal of Law and Economics, 21(2), 297-326. https://doi.org/10.1086/46692 2.

Koenig, P. (2012). The effect of LNG on the relationship between UK and continental natural gas markets. EPRG working paper series N1225. http://www.eprg.group.cam.ac.uk/wp-content/uploa ds/2014/01/1225-PDF.pdf. Accessed May 2018.

Makholm, J. D. (2012). The political economy of pipelines: A century of comparative institutional development. Chicago: The University of Chicago Press.

Makholm, J. D. (2015). Regulation of natural gas in the United States, Canada, and Europe: Prospects for a low carbon fuel. Review of Environmental Economics and Policy, 9(1), 107-127. https://doi. org/10.1093/reep/reu017.

Masten, S., \& Croker, K. (1985). Efficient adaptation in long-term contracts: Take-or-pay provisions for natural gas. The American Economic Review, 75(5), 1083-1093.

Miriello, C., \& Polo, M. (2015). The development of gas hubs in Europe. Energy Policy, 84, 177-190.

Mulherin, J. H. (1986). Complexity in long-term contracts: An analysis of natural gas contractual provisions. Journal of Law, Economics and Organisation, 2(1), 105-117.

Neumann, A. (2009). Linking natural gas markets-Is LNG doing its job? The Energy Journal, 30(special issue 1), 187-199. https://doi.org/10.5547/ISSN0195-6574-EJ-Vol30-NoSI-12. 
Neumann, A., \& Cullman, A. (2012). What's the story with natural gas markets in Europe? Empirical evidence from spot trade data. In 9th International conference european energy market (EMM), May 2012. https://doi.org/10.1109/eem.2012.6254679.

Neumann, A., Ruester, S., \& Hirschhausen, C. V. (2015). Long-term contracts in the natural gas industry: Literature survey and data of 426 contracts (1965-2014). Data documentation 77, DIW Berlin. https://www.diw.de/documents/publikationen/73/diw_01.c.498163.de/diw_datadoc_2015-077.pdf. Accessed 7 August 2015.

Neumann, A., Siliverstovs, B., \& von Hirschhausen, C. (2006). Convergence of European spot market prices for natural gas? A real-time analysis of market integration using the Kalman Filter. Applied Economics Letters, 2006(13), 727-732.

Noel, P. (2009). A market between us: Reducing the cost of Europe's dependence on Russian gas. University of Cambridge, EPRG working paper 0916.

Parsons, J. E. (1989). Estimating the strategic value of long-term forward purchase contracts using auction models. Journal of Finance, 44(4), 981-1010. https://doi.org/10.1111/j.1540-6261.1989.tb026 34.x.

Petrovich, B. (2013). European gas hubs: How strong is price correlation?. OIES working paper series NG79. https://www.oxfordenergy.org/wpcms/wp-content/uploads/2013/10/NG-79.pdf. Accessed May 2018.

REKK. (2016). The preconditions for market integration compatible gas transmission tariffs in the CESEC region. A CESEC discussion paper. https://ec.europa.eu/energy/sites/ener/files/documents/ Gas_transmission_tariff_CESEC_final_10_05_18.pdf. Accessed May 2018.

Ruester, S. (2009). Changing contract structures in the international liquefied natural gas market: A first empirical analysis. Revue d'économie industrielle, 127(3), 89-112.

Siliverstovs, B., L'Hegaret, G., Neumann, A., \& von Hirschhausen, C. (2005). International market integration for natural gas? A cointegration analysis of prices in Europe, North America and Japan. Energy Economics, 27(2005), 603-615. https://doi.org/10.1016/j.eneco.2005.03.002.

Société Générale (SG). (2013). What lies ahead after oil indexation for Europe? SG commodities research report. Accessed through the Bloomberg Terminal.

Stern, J. (2006). The new security environment for European gas: Worsening geopolitics and increasing global competition for $L N G$. Oxford Institute for Energy Studies, working paper NG15. http://www. oxfordenergy.org/wpcms/wp-content/uploads/2010/11/NG15-TheNewSecuirtyEnvironmentForEu ropeanGasWorseningGeopoliticsandIncreasingGlobalCompetitionforLNG-JonathanStern-2006.pdf. Accessed May 2018.

von Hirschhausen, C., \& Neumann, A. (2008). Long-term contracts and asset specificity revisited: An empirical analysis of producer-importer relations in the natural gas industry. Review of Industrial Organization, 32(2), 131-143. https://doi.org/10.1007/s11151-008-9165-0.

Williamson, O. E. (1971). The vertical integration of production: Market failure considerations. American Economic Review, 61(2), 112-123.

Williamson, O. E. (1975). Markets and hierarchies: Analysis and antitrust implications: A study in the economics of internal organization. New York: Free Press.

Williamson, O. E. (1979). Transaction cost economics: The governance of contractual relations. Journal of Law and Economics, 22(2), 233-261.

Williamson, O. E. (1983). Credible commitments: Using hostages to support exchange. American Economic Review, 73(4), 519-540.

Williamson, O. E. (1985). The economic institutions of capitalism: Firms, markets, relational contracting. New York: Free Press.

Publisher's Note Springer Nature remains neutral with regard to jurisdictional claims in published maps and institutional affiliations. 